\title{
Chromosome abnormalities in Japanese quail embryos
}

\author{
CA de la Sena ${ }^{1}$, NS Fechheimer ${ }^{1,2,3 *}$, KE Nestor ${ }^{3}$ \\ The Ohio State University, Departments of ${ }^{1}$ Molecular Genetics, \\ ${ }^{2}$ Dairy Science and ${ }^{3}$ Poultry Science, Columbus, OH, USA
}

(Proceedings of the 9th European Colloquium on Cytogenetics of Domestic Animals; Toulouse-Auzeville, 10-13 July 1990)

Japanese quail / embryos / heteroploidy / chromosomes

\section{INTRODUCTION}

Embryos of the domestic chicken have been used extensively to elucidate questions regarding the extent to which heteroploidy is a cause of embryonic mortality, the sources of errors leading to various types of heteroploid zygotes and the etiology of heteroploid zygotes and embryos (Fechheimer, 1981, 1990). The Japanese quail possesses many of the attributes of the chicken, as well as others that contribute further to its usefulness for such work. Quail hens have a mature body weight of only about $100 \mathrm{~g}$, produce eggs at the same rate as chickens and reach sexual maturity at about 6 weeks of age. The incubation period is only 18 days. The karyotype of the quail is similar to that of chicken, comprising 38 pairs of autosomes and $\mathrm{Z}$ and $\mathrm{W}$ gonosomes. Eight autosomal pairs and the $\mathrm{Z}$ and $\mathrm{W}$ are relatively long and have sufficiently distinctive morphology that each can be readily recognized in metaphase plates (Talluri and Vegni, 1965; Ansari and Singh, 1983). The W is largely heterochromatic and stains densely when C-banding procedures are applied. Variants of chromosomes 4 and $\mathrm{Z}$ have been identified by C-banding in several populations and are valuable as markers.

The present study was undertaken to explore the suitability of Japanese quail as a model vertebrate system in which genetic factors might be identified that disrupt the orderly sequence of the reproductive cycle, thus resulting in the occurrence of various types of heteroploidy in embryos.

\section{MATERIALS AND METHODS}

A population of Japanese quail is maintained by mating of 36 pairs. The male and female for each paired mating are chosen at random. The 36 males and females

\footnotetext{
*To whom correspondence should be addressed: Department of Dairy Science, 2027 Coffey
} Road, Columbus, OH 43210, USA. 
represent each of the 36 families (Nestor et al, 1982). In the present study, matings were made between 36 pairs of full sibs, one pair from each of the families of the randomly mated population. Eggs were collected in sufficient quantity to enable karyological analysis of 20 embryos from each family. Additional eggs were then incubated to reproduce the family. Infertile pairs were replaced by additional pairs from the same family when it was possible to do so. Otherwise, replacements were chosen from one of the other remaining families. The process was repeated for 3 generations.

Following $16 \mathrm{~h}$ of incubation, eggs were injected with $0.06 \mathrm{ml}$ of a $0.2 \%$ solution of colchicine and returned to the incubator for $2 \mathrm{~h}$. Embryos were prepared for karyological examination according to the procedure of Miller et al (1971) that has been applied extensively for chicken embryos. Routinely, 10 cells from each embryo were examined. If one or more was aberrant, additional cells were examined to establish the extent of mixoploidy.

Analysis of variance was applied, using two different models, to test for significance of differences in the incidences of each type of abnormality among the 36 inbred lines (lineages) and 107 full sib families each of which comprised about 20 embryos.

\section{RESULTS AND DISCUSSION}

A total of 2893 eggs was inspected, of which 2037 (70\%) contained embryos that were successfully analyzed. Of the remainder, $17 \%$ were infertile, $4.8 \%$ contained dead embryos, $3.2 \%$ were destroyed during processing and $4.6 \%$ contained live embryos that could not be analyzed because too few metaphase plates were present on the slide.

The frequencies of various types of heteroploid embryos, embryos in which one or more cells contained a structural aberration and embryos in which all the chromosomes in all cells exhibited a particular atypical configuration are shown in table I. The overall frequency of embryos bearing chromosome abnormalities was $15.3 \%$ and all categories of abnormalities, except aneuploidy and structural aberrations, had frequencies of $1.0 \%$ or greater. Aneuploidy was relatively infrequent because it could be observed for only 8 of the 38 pairs of autosomes; 4 of the aneuploids involved the sex chromosomes.

For several of the types of heteroploidy, the origins of the error can be inferred from their sex chromosome complements or by analogy with similar observations of chicken embryos bearing marker chromosomes that were possessed by only one parent (Fechheimer and Jaap, 1978, 1980). The presumed or known sites of origin for each type of abnormality are given in table I. Arguments in support of these inferences are given in a previous communication (Fechheimer, 1981).

Of particular interest is a new type of aberration referred to as atypical mitotic metaphase. This aberration is characterized by metaphase chromosomes with the two chromatids parallel to one another and not exhibiting the usual constriction at the centromere region. It is unlike other similar, previously described aberrations, such as C-mitosis, endoreduplication and premature centromere division. It was seen in all metaphase cells from 20 embryos. The 20 affected embryos were clustered in 
Table I. Incidence, inferred origins and evidence for genetic control of chromosomal abnormalities in a sample of 2037 Japanese quail embryos.

\begin{tabular}{|c|c|c|c|}
\hline Type of abnormality & $\begin{array}{l}\text { Incidence } \\
\text { (per } 1000)\end{array}$ & $\begin{array}{l}\text { Inferred } \\
\text { origin }\end{array}$ & $\begin{array}{l}\text { Distribution in } \\
\text { full sib families } \\
\text { and inbred lineages }\end{array}$ \\
\hline $\begin{array}{l}\text { Triploid \& triploid } \\
\text { chimeras } \\
3 n ; 1 n / 3 n ; 2 n / 3 n\end{array}$ & 24 & $\begin{array}{l}\text { suppression of MII } \\
\text { of oocyte }(\sim 59 \%) \\
\text { suppression of MI } \\
\text { of oocyte }(\sim 14 \%) \\
\text { diandry }(\sim 29 \%)\end{array}$ & $\begin{array}{l}\text { non-random among } \\
\text { families }(P<0.01) \\
\text { and lineages } \\
(P<0.05)\end{array}$ \\
\hline $\begin{array}{l}\text { Haploid \& haploid } \\
\text { chimeras } \\
1 n ; 1 n / 2 n ; 1 n / 3 n\end{array}$ & 26 & $\begin{array}{l}\text { proliferation of } \\
\text { spermatozoa } \\
\text { by mitosis }\end{array}$ & $\begin{array}{l}\text { non-random among } \\
\text { families }(P<0.01) \\
\text { and lineages } \\
(P<0.05)\end{array}$ \\
\hline $\begin{array}{l}\text { Diploid/tetraploid } \\
\text { mosaics } \\
2 n / 4 n\end{array}$ & 32 & $\begin{array}{l}\text { suppression of } \\
\text { mitosis of } \\
\text { cleavage } \\
\text { division }\end{array}$ & $\begin{array}{l}\text { non-random among } \\
\text { families }(P<0.01) \\
\text { random among } \\
\text { lineages }(P>0.25)\end{array}$ \\
\hline $\begin{array}{l}\text { Aneuploid mosaic } \\
2 n / 2 n \pm 1\end{array}$ & 46 & $\begin{array}{l}\text { non-disjunction } \\
\text { or lagging at } \\
\text { a cleavage } \\
\text { division }\end{array}$ & $\begin{array}{l}\text { random among families } \\
(P>0.05) ; \text { non-random } \\
\text { among lineages } \\
(P<0.01)\end{array}$ \\
\hline $\begin{array}{l}\text { Aneuploid } \\
2 n \pm 1\end{array}$ & 8 & $\begin{array}{l}\text { non-disjunction } \\
\text { or lagging at } \\
\text { meiosis }\end{array}$ & $\begin{array}{l}\text { random among families } \\
(P>0.10) \text { and } \\
\text { lineages }(P>0.25)\end{array}$ \\
\hline $\begin{array}{l}\text { Atypical mitotic } \\
\text { metaphase }\end{array}$ & 10 & $\begin{array}{l}\text { altered } \\
\text { centromere? }\end{array}$ & $\begin{array}{l}\text { random among lineages } \\
(P>0.25) ; \text { non-random } \\
\text { among families }(P<0.01)\end{array}$ \\
\hline $\begin{array}{l}\text { Structural } \\
\text { aberrations in } \\
\text { one or more cells }\end{array}$ & 7 & $\begin{array}{l}\text { non-repair of } \\
\text { break }\end{array}$ & $\begin{array}{l}\text { random among } \\
\text { families and lineages } \\
(P>0.25 \text { for both })\end{array}$ \\
\hline
\end{tabular}

only 5 of the 107 families, indicating that the anomaly is probably caused by a genetic factor.

The results of analysis of variance for differences in frequency of the several abnormalities among families and lineages is shown in table I. Significant differences are interpreted as non-random distribution of a particular abnormality among families or lineages. Such non-random distribution, ie, clustering, is considered to be strong evidence for genetic influence as an etiological element. Triploidy, haploidy, diploid/tetraploid mosaicism and atypical mitotic metaphase all were found to cluster within certain families and both triploidy and haploidy as well as aneuploid mosaicism were found to be non-randomly distributed among lineages. No evidence for genetic control of aneuploidy or structural aberrations was found.

From 36 inbred lines started from a randomly mated population, only 16 survived to produce embryos in the third generation. The remaining 20 lineages could not be continued because full sib matings did not yield viable and fertile replacements, in spite of full opportunity afforded to them to do so. However, from 
only 36 original matings, evidence was obtained for the existence of mutant genes, segregating in the random mating population, that detrimentally affect several stages of the reproductive cycle. Interference with the normal course of both first and second meiotic divisions is indicated by the triploids. Anomalies of fertilization resulted in the occurrence of the haploid chimeras and a few of the triploids. Disruption of normal mitosis during cleavage divisions resulted in production of diploid/tetraploid and diploid/aneuploid mosaics, and the aberration called atypical mitotic metaphase.

It is reasonable to suppose that genes with such detrimental effects occur at low frequencies in the base population. Because each lineage was reproduced in each generation from only two parents, a large proportion of such genes was eliminated from each lineage, by chance, in 3 generations of full sib mating. Therefore, the detection of the occurrence of a few genes that cause disruption of meiosis and mitosis in this experiment indicates that probably many more were present in the base population. It should be possible to detect many of them by further experimentation with this or similar populations of Japanese quail. The Japanese quail appears to provide an excellent vertebrate system for the detection and subsequent characterization of meiotic and mitotic mutant genes similar to those that have been so thoroughly studied in yeast, drosophila and plants (reviewed by Baker et al, 1976).

\section{ACKNOWLEDGMENTS}

Gratitude is extended to Mr John Anderson who provided excellent care for the experimental animals. Salaries and research support were partly provided by funds appropriated to The Ohio Agricultural Research and Development Center.

\section{REFERENCES}

Ansari HA, Singh H (1983) The chromosome complements of Japanese quail (Coturnix coturnix japonica). Avian Res 67, 81-84

Baker BS, Carpentier ATC, Esposito MS, Esposito RE, Sandler L (1976) Genetic control of meiosis. Annu Rev Genet 10, 53-134

Fechheimer NS (1981) Origins of heteroploidy in chick embryos. Poult Sci 60, 1365-1371

Fechheimer NS (1990) The domestic chicken (Gallus domesticus) as an organism for the study of chromosomal aberrations. In: Farm Animals in Biochemical Research (Pliska V, Stranzinger G, eds). Verlag Paul Parey, Hamburg

Fechheimer NS, Jaap RG (1978) The parental sources of heteroploidy in chick embryos determined with chromosomally marked gametes. $J$ Reprod Fertil 52, 141-146

Fechheimer NS, Jaap RG (1980) Origins of euploid chimerism in embryos of Gallus domesticus. Genetica 52/53,69-72

Miller RG, Fechheimer NS, Jaap RG (1971) Chromosome abnormalities in 16- to 18-hour chick embryos. Cytogenetics 10, 121-136

Nestor KE, Bacon WL, Lambio AL (1982) Divergent selection for body weight and yolk precursor in Coturnix coturnix japonica. 1. Selection response. Poult Sci 61, 12-17

Talluri MV, Vegni L (1965) Fine resolution of the karyogram of the quail Coturnix coturnix japonica. Chromosoma 17, 264-272 